\title{
HUBUNGAN HARGA DENGAN KEPUASAN PASIEN DI RUMAH SAKIT BHAKTI MEDICARE, CICURUG, KABUPATEN SUKABUMI
}

\author{
Hasrul \\ Fakultas Ekonomi Universitas Pakuan \\ Email: hasrul@unpak.ac.id
}

\section{ARTICLE INFO \\ Article History: \\ Received 22 May 2018 \\ Revised 15 June 2018 \\ Accepted 15 July 2018}

\section{JEL Classification:}

E31, P22

\section{Keywords:}

Price,

Patient Satisfaction, and Payment Period

\section{ABSTRACT}

The purpose of this study is to determine the presence or absence of price relationships with patient satisfaction in Bhakti Medicare, Cicurug, Sukabumi. The population of this research is 130 Bhakti Medicare's patients, Cicurug, Sukabumi consisting of patients in Jasmine Room, Rose Room, Dahlia Room and Orchid Room. This amount fulfills the minimum sample for Slovin formula. The collected data is then processed using simple correlation and multiple correlation techniques using SPSS software. The results show that there is positive relation between price and satisfaction with correlation coefficient value equal to $\left(r_{y .1}\right)=0,679$, while price contribution to patient satisfaction equal to $r^{2}=\left(r_{y .1}\right)^{2}=46,2 \%$. In addition, price contribution is considered strong against patient satisfaction which means increased price will ensure patient satisfaction in Bhakti Medicare hospital, Cicurug, Sukabumi regency. In the most important dimension of price variable, the relationship is the dimension of "payment period" $\left(X_{14}\right)$ which has the strongest relationship with "consistency" dimension $\left(Y_{3}\right)$ on patient satisfaction variable with correlation coefficient 0,641. Therefore it can be concluded that the price dimension that most determine patient satisfaction at Bhakti Medicare Hospital, Cicurug, Sukabumi Regency is the dimension of price.

\section{PENDAHULUAN}

Rumah Sakit Bhakti Medicare merupakan salah satu rumah sakit yang berada di Kecamatan Cicurug, Kabupaten Sukabumi, tepatnya JI Raya Siliwangi No 186 B CicurugSukabumi. Rumah sakit Bhakti Medicare ini bergerak di bidang pelayanan kesehatan, dengan moto: "Melayani dengan sepenuh hati", dengan demikian kepuasan pasien merupakan salah satu tujuannya. Berikut ini merupakan jumlah kunjungan pasien, baik rawat inap maupun rawat jalan di Rumah Sakit Bhakti Medicare.
Data menunjukkan bahwa pasien Rumah Sakit Bhakti Medicare mulai mengalami penurunan tahun 2012 sampai 2014 sebanyak 1.130 pasien atau sebesar $7,9 \%$ padahal pada saat yang sama terjadi peningkatan pasien yang sangat significant pada Rumah Sakit Umum Daerah Syamsudin, Sukabumi yaitu sebanyak 1.200 pasien.

Untuk target kunjungan menunjukkan bahwa jumlah pasien yang berobat di Rumah Sakit Bhakti Medicare masih di bawah target yaitu $66 \%$ dari target yang dibebankan manajemen sedangkan jumlah pasien yang 
menggunakan layanan ulang mengalami penurunan sebesar $4 \%$.

Bahkan data keluhan (complain) menunjukkan peningkatan pada periode tahun 2013 dan 2014 yang diasumsikan bahwa penurunan kualitas pelayanan terhadap Rumah Sakit Bhakti Medicare yaitu naik sebesar $2 \%$. Dari data ini diasumsikan bahwa penurunan ini disebabkan adanya perubahan tingkat kepuasan terhadap rumah sakit.

Pengujian tahap awal dapat diperoleh data sebanyak $42 \%$ pasien belum puas menggunakan jasa rumah sakit Bhakti Medicare sebagai sarana untuk penyembuhan dan berobat serta menjaga hubungan baik dengan rumah sakit. Sebanyak 33\% pasien tidak selalu membeli obat dari apotek rumah sakit. Sebanyak $35 \%$ pasien tidak melakukan pengecekan rutin setiap bulan dan $38 \%$ tidak merekomendasikan rumah sakit Bhakti Medicare untuk menangani kesehatan kepada kerabat dan teman.

\section{Perumusan Masalah}

Perumusan masalah dalam penelitian ini adalah apakah ada hubungan harga dengan kepuasan pasien di Rumah Sakit Bhakti Medicare, Cicurug, Kabupaten Sukabumi?

\section{Tujuan Penelitian}

Tujuan dari penelitian ini adalah untuk menjawab permasalahan penelitian yaitu Apakah ada hubungan antara harga dengan tingkat kepuasan pasien.

\section{KAJIAN LITERATUR Kepuasan Pelanggan}

Kepuasan pelanggan adalah hasil akumulasi dari konsumen atau pelanggan dalam menggunakan produk atau jasa. (Irawan, 2002).

Zeithaml, et al. (2009) mendefinisikan bahwa "service quality, the customer's perception of the service component of a product, is also a critical determinant of customer satisfaction". Kualitas layanan merupakan persepsi pelanggan atas komponen pelayanan sebuah produk, dan juga merupakan penentu yang penting dalam mencapai kepuasan pelanggan. Indikator dari kualitas pelayanan yaitu : 1) Keandalan (reliabilty); 2) Daya Tanggap (responsiveness); 3) Jaminan (assurance); 4) Empati dan 5) Bukti Fisik.

\section{Harga}

Harga adalah sejumlah uang yang harus dibayar oleh pelanggan atau pertukaran untuk menerima barang atau jasa. (Baines, et al., 2011). Tjiptono (2007) menyatakan bahwa harga merupakan satuan moneter atau ukuran lainnya (termasuk barang dan jasa lainnya) yang ditukarkan agar memperoleh hak kepemilikan atau penggunaan suatu barang atau jasa. Dan indikator dari harga adalah : 1 ) Daftar harga; 2) Potongan harga; 3) Periode pembayaran.

\section{Hasil Penelitian yang Relevan}

Hasil-hasil penelitian terdahulu yang relevan digunakan untuk memberikan gambaran tentang posisi dan kelayakan penelitian tentang hubungan antara harga dengan kepuasan pasien.

Tabel 1. Hubungan Harga dengan Kepuasan

\begin{tabular}{|c|c|c|c|c|c|}
\hline \multicolumn{6}{|c|}{ Pasien } \\
\hline \multirow[t]{2}{*}{ Model } & \multicolumn{2}{|c|}{$\begin{array}{l}\text { Unstandardized } \\
\text { Coefficients }\end{array}$} & \multirow{2}{*}{$\begin{array}{l}\text { Standardized } \\
\text { Coefficeients } \\
\text { Beta }\end{array}$} & \multirow[t]{2}{*}{$\mathrm{t}$} & \multirow[t]{2}{*}{ Sig. } \\
\hline & $B$ & $\begin{array}{l}\text { Std. } \\
\text { Error }\end{array}$ & & & \\
\hline \multirow{2}{*}{$\begin{array}{l}\text { Constant } \\
\text { Price }\end{array}$} & 2.251 & .248 & & 10.174 & .000 \\
\hline & .352 & .071 & .348 & 4.936 & .000 \\
\hline
\end{tabular}

Umar (2015) menyebutkan bahwa "Price is significantly predicting customer satisfaction with 0.348 units change per one unit change in price". Tabel 1 menunjukkan hubungan antara harga $(X)$ dan kepuasan pelanggan $(Y)$. Harga secara signifikan memprediksi kepuasan pelanggan dengan 0,348 unit berubah per satu unit perubahan harga sehingga diasumsikan harga berhubungan erat dengan kepuasan pasien.

Harjati dan Venesia (2015) meneliti mengenai pengaruh kualitas layanan dan harga 
terhadap kepuasan pelanggan pada maskapai penerbangan Tiger Air Mandala menunjukkan bahwa kualitas layanan (variabel $X_{1}$ ) memiliki nilai t hitung $=3,980$ dengan tingkat signifikansi 0,000 . Dengan menggunakan batas signifikansi 0,05 , nilai signifikansi tersebut lebih kecil dari taraf 5\%. Kemudian harga (variabel X2) memiliki nilai $t$ hitung $=5,150$ dengan tingkat signifikansi 0,000 . Dengan menggunakan batas signifikansi 0,05, nilai signifikansi tersebut lebih kecil dari taraf $5 \%$, yang berarti Ho ditolak dan Ha diterima. Dengan demikian, maka Hipotesis kedua diterima. Selanjutnya nilai $R$ menunjukkan angka sebesar 0,744 yang berarti kualitas layanan dan harga memiliki hubungan yang positif dengan kepuasan pelanggan. Sedangkan nilai adjusted $\mathrm{R}$ square menunjukkan angka 0,545 yang berarti $54,5 \%$ variabel kepuasan pelanggan dapat dijelaskan oleh variabel kualitas layanan dan harga dan sisanya $45,5 \%$ dijelaskan oleh faktor-faktor lain.

Artiningtyas (2015) meneliti mengenai pengaruh kualitas layanan harga dan kepercayaan terhadap kepuasan pelanggan di Toko Vulkanisir Ban Top Cool, Semarang. Tujuan penelitian untuk menganalisis pengaruh kualitas layanan, harga dan kepercayaan terhadap kepuasan pelanggan pada Toko Vulkanisir Ban Top Cool Semarang. Dengan teknik pengambilan sampel purposive sampling, kriteria yang digunakan adalah konsumen yang menggunakan produk dan jasa pada Toko Vulkanisir Ban Top Cool Semarang minimal sudah 2 kali dan bersedia dijadikan responden pada saat dilakukan penyebaran kuesioner. Dari teknik ini diperoleh 97 responden. Hasil penelitian menunjukkan bahwa harga lebih berpengaruh positif terhadap kepuasan pelanggan dengan koefisien regresi sebesar 0,325 ; selanjutnya kepercayaan juga berpengaruh positif terhadap kepuasan pelanggan dengan koefisien regresi sebesar 0,309 dan kualitas layanan berpengaruh positif terhadap kepuasan pelanggan dengan koefisien regresi sebesar 0,218 .

\section{Rerangka Penelitian}

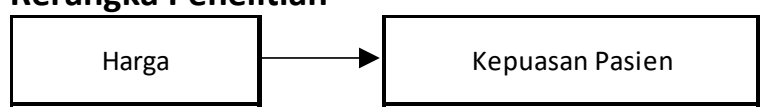

Gambar 1. Kerangka Pemikiran

Berdasarkan kerangka penelitian diatas maka dirumuskan hipotesis penelitan adalah harga berhubungan erat dengan kepuasan pasien.

\section{METODA PENELITIAN}

Metoda penelitian yang digunakan berupa metoda survey, dengan pendekatan korelasional, yaitu metode penelitian yang dirancang untuk mendapatkan informasi tentang hubungan antara variabel-variabel yang berbeda dalam satu populasi. Objek dalam penelitian ini adalah harga sebagai variabel independen dan tingkat kepuasan pasien sebagai variabel dependen. Tujuan penelitian ini adalah untuk menguji hubungan variabel independen yaitu harga $(X)$ terhadap variabel dependen yaitu tingkat kepuasan pasien $(Y)$ dengan menggunakan teknik korelasi product moment.

Populasi penelitian ini adalah pasien rumah sakit Bhakti Medicare, Cicurug, Kabupaten Sukabumi yang merupakan pasien pada ruangan melati, ruangan mawar, ruangan dahlia dan ruangan anggrek sebanyak 130 pasien dengan 100 responden. Sedangkan sampel diambil dengan teknik pengambilan sampel judgement sampling atau purposive sampling yaitu pengambilan sampel dilakukan berdasarkan pertimbangan yang sesuai dengan maksud penelitian.

Selanjutnya data dikumpulkan dengan menggunakan kuesioner yaitu teknik pengumpulan data dengan memberikan daftar pertanyaan tertulis kepada pasien di Rumah Sakit Bhakti Medicare, Cicurug, Kabupaten Sukabumi sebagai responden. Terakhir kuesioner dimodifikasi sehingga sesuai dengan tujuan pengambilan data, karena itu kuesioner ini telah ditentukan isi dan materinya. 
Hasrul: Hubungan Harga dengan ...

\section{Pengukuran Variabel Penelitian}

Variabel-variabel independen (harga) dan variabel dependen (tingkat kepuasan) yang merupakan skala interval diukur menggunakan skala Likert (Indriantoro dan Supomo, 2002) dengan angka penilaian 1 sampai dengan 5 .

\section{Analisis Data}

Pengujian kualitas data atas data kualitatif yang digunakan dalam penelitian ini menggunakan uji validitas, uji normalitas (one sample Kolmogorov Smirnov), uji homogenitas varians (bartlet) dan Uji linieritas. Kemudiaan perhitungan pengujian dilakukan memakai bantuan software SPSS. Uji validitas menggunakan rumus korelasi product moment dari Karl Pearson, sedangkan uji reliabilitas menggunakan rumus Cronbach Alpha.

\section{Pengujian Hipotesis}

Untuk menguji kriteria hipotesis diterima atau ditolak, maka dilakukan uji asumsi klasik yaitu uji korelasi sederhana product moment dari Karl Pearson untuk menguji kekuatan hubungan variable $\mathrm{X}$ (independent) dengan variable $Y$ (dependen).

\section{Analisis Dimensi}

Analisis dimensi digunakan untuk mengetahui hubungan antara dimensi-dimensi pada variabel bebas dengan dimensi-dimensi variabel terikat. Analisis dimensi dilakukan dengan cara membuat matriks korelasi dimensi antar variabel.

\section{HASIL PENELITIAN DAN PEMBAHASAN \\ Deskripsi Statistik Data Variabel Terikat Kepuasan pasien $(\mathrm{Y})$}

Tabel 2. Kepuasan Pasien

\begin{tabular}{|c|c|c|}
\hline $\mathrm{N}$ & Valid & 100 \\
\hline & Missing & 0 \\
\hline Mean & & 123.8400 \\
\hline Median & & 143.5000 \\
\hline Mode & & 138.00 \\
\hline Std. Deviation & & 13.29291 \\
\hline Variance & & 176.701 \\
\hline Range & & 113.00 \\
\hline Minimum & & 60.00 \\
\hline Maximum & & 173.00 \\
\hline Sum & & 14384.00 \\
\hline
\end{tabular}

Berdasarkan hasil penelitian terhadap variabel kepuasan pasien dengan 35 buah pertanyaan yang valid, diperoleh skor empirik terendah adalah 60 dan tertinggi 173 dengan rentang skor 113 . Rangkuman data seperti tertera pada deskripsi data sebagai berikut:

Diperoleh nilai mean untuk variabel kepuasan pasien 143,84, median sebesar 143,50 , mode sebesar 138,00 , dan standar deviasi sebesar 13,29. Variance data kepuasan pasien menunjukkan nilai sebesar 176,701 , dan banyak kelas interval 8 dengan frekuensi paling rendah sebesar 3\% responden menyatakan kepuasan pasien berada pada interval skor 6073. Kemudian frekuensi relatif paling tinggi sebesar $29 \%$ responden menyatakan kepuasan pasien berada pada interval skor 130 - 143 .

Butir pertanyaan kepuasan pasien terdiri dari 35 soal valid, skor teoretis terendah adalah 35 dan skor tertinggi adalah 175, dengan median teoretis adalah $(35+175: 2) 105$, skor empirik ( hasil penelitian ) terendah adalah 60 dan skor tertinggi adalah 173 , dengan median empirik $(60+173: 2) 116$ berarti skor empirik bergerak pada daerah skor tinggi, dengan demikian kepuasan pasien termasuk dalam kategori tingkat tinggi. 
Deskripsi Statistik Data Variabel Bebas Harga (X)

Tabel 3. Harga

\begin{tabular}{lrr}
\hline $\mathrm{N}$ & Valid & 100 \\
\hline \multicolumn{1}{c|}{ Missing } & 0 \\
\hline Mean & 150.9900 \\
\hline Median & 148.0000 \\
\hline Mode & 148.00 \\
\hline Std. Deviation & 15.99274 \\
\hline Variance & 255.768 \\
\hline Range & 142.00 \\
\hline Minimum & 43.00 \\
\hline Maximum & 185.00 \\
\hline Sum & 15099.00 \\
\hline
\end{tabular}

Dari Tabel Harga diperoleh skor empirik terendah adalah 43 dan tertinggi 185 dengan rentang skor 142. Hasil analisis data diperoleh nilai mean untuk variabel harga 150,99 , median sebesar 148,00, mode sebesar 148,00, dan standar deviasi sebesar 15,99. Kemudian variance data harga menunjukkan nilai sebesar 255,76 , dengan banyak kelas interval 8 dengan frekuensi paling rendah sebesar $1 \%$ responden menyatakan harga berada pada interval skor 43 -60 . Sedangkan frekuensi relatif paling tinggi $24 \%$ responden menyatakan harga berada pada interval skor 133 - 150. Pertanyaan harga terdiri dari 37 soal valid, skor teoretis terendah adalah 37 dan skor tertinggi adalah 185, dengan median teoretis adalah $(37+185: 2) 111$, skor empirik (hasil penelitian) terendah adalah 43 dan skor tertinggi adalah 185, dengan median empirik $(43+185: 2) 114$ berarti skor empirik bergerak pada daerah skor tinggi, dengan demikian harga termasuk dalam kategori tingkat tinggi.

\section{PENGUJIAN HIPOTESIS}

Tabel 4. Hubungan antara harga $(X)$ dengan

\begin{tabular}{|c|c|c|c|c|c|}
\hline \multirow[t]{2}{*}{ Model } & \multicolumn{2}{|c|}{$\begin{array}{l}\text { Unstandardized } \\
\text { Coefficients }\end{array}$} & \multirow{2}{*}{$\begin{array}{l}\text { Standardized } \\
\text { Coefficeients } \\
\text { Beta }\end{array}$} & \multirow[t]{2}{*}{$\mathrm{t}$} & \multirow[t]{2}{*}{ Sig. } \\
\hline & B & $\begin{array}{l}\text { Std. } \\
\text { Error }\end{array}$ & & & \\
\hline \multirow{2}{*}{$\begin{array}{l}\text { Constant } \\
\text { Price }\end{array}$} & 58.581 & 9.354 & & 6.262 & .000 \\
\hline & .565 & .062 & .679 & 9.165 & .000 \\
\hline
\end{tabular}

1. Sesuai dengan hipotesis penelitian, maka hubungan antara harga dengan kepuasan pasien dengan menggunakan teknik korelasi product moment diperoleh koefisien korelasi $r_{y \cdot 1}=0,679$. Ini menunjukkan hubungan yang kuat antara variabel harga dengan variabel kepuasan pasien.

2. Kontribusi harga (X) dengan kepuasan pasien $(\mathrm{Y})$ dihitung berdasarkan koefisien determinasi yaitu $r^{2}=\left(r_{y .1}\right)^{2}=0,462$. Berarti variabel harga memberikan kontribusi sebesar $46,2 \%$ terhadap kepuasan pasien (Y), sisanya sebesar 53,8\% (100\%-46,2\%) dipengaruhi variabel lain.

3. Hubungan Fungsional antara harga dengan kepuasan pasien dapat dilihat pada persamaan:

$$
\hat{Y}=58,581+0,565 X
$$

Persamaan diatas menunjukkan bahwa harga berpengaruh positif terhadap kepuasan pelanggan dengan koefisien regresi sebesar 0,565 yang artinya kepuasan pasien akan meningkat 0,565 satuan apabila variable harga (X) meningkat satu satuan dengan konstansta 58,581 .

4. Hasil uji linieritas memperlihatkan nilai $F$ test $=130,484$ mencapai taraf signifikan.

5. Untuk menguji hipotesis bahwa terdapat hubungan positif antara variabel $X$ dengan $Y$ diperlukan uji signifikansi koefisien korelasi yaitu dengan uji t.

$\mathrm{H}_{\mathrm{o}}=$ Tidak terdapat hubungan positif antara harga dengan kepuasan pasien.

$\mathrm{H}_{\mathrm{a}}=$ Terdapat hubungan positif antara harga dengan kepuasan pasien.

Kriteria pengujian signifikansi koefisien korelasi adalah jika t-hitung $>$ t-tabel. Dari table 24 Coefficients diperoleh $\mathrm{t}$-hitung $=$ 9,165 , tingkat Sig $=0,05$ dan $\mathrm{N}-1$ atau 100 
Hasrul: Hubungan Harga dengan ...

-1 = 99 didapat $\mathrm{t}$-tabel = 1,6604. Ternyata bahwa nilai t-hitung > t-tabel atau 9,165 > 1,6604, berarti harga $(X)$ signifikan terhadap kepuasan pasien $(\mathrm{Y})$.

\section{ANALISIS DIMENSI}

Analisis dimensi digunakan untuk mengetahui hubungan antara dimensi-dimensi pada variabel bebas dengan dimensi-dimensi variabel terikat. Analisis dimensi dilakukan dengan cara membuat matriks korelasi dimensi antar variabel. Hasil analisis dimensi terhadap variabel-variabel penelitian dapat dilihat pada tabel dibawah ini.

Tabel 5. Analisis Dimensi

\begin{tabular}{|c|c|c|c|c|c|c|}
\hline & & \multirow{2}{*}{$\begin{array}{l}\text { Variabel } \\
\text { Dimensi } \\
\end{array}$} & \multicolumn{4}{|c|}{$Y$} \\
\hline & & & $Y_{1}$ & $Y_{2}$ & $Y_{3}$ & $Y_{4}$ \\
\hline \multirow{12}{*}{$x$} & \multirow{2}{*}{$X_{11}$} & $\begin{array}{l}\text { Pearson } \\
\text { Correlation }\end{array}$ & $.480 * *$ & $.572 * *$ & $.504^{* *}$ & $.410 * *$ \\
\hline & & $\begin{array}{l}\text { Sig. (2- } \\
\text { tailed) }\end{array}$ & .000 & .000 & .000 & .000 \\
\hline & \multirow{2}{*}{$X_{12}$} & $\begin{array}{l}\text { Pearson } \\
\text { Correlation }\end{array}$ & $.569 * *$ & $.619^{* *}$ & $.595 * *$ & $.462^{* *}$ \\
\hline & & $\begin{array}{l}\text { Sig. (2- } \\
\text { tailed) }\end{array}$ & .000 & .000 & .000 & .000 \\
\hline & \multirow{2}{*}{$X_{13}$} & $\begin{array}{l}\text { Pearson } \\
\text { Correlation }\end{array}$ & $.426 * *$ & $.537^{* *}$ & $.560^{* *}$ & $.267^{* *}$ \\
\hline & & $\begin{array}{l}\text { Sig. (2- } \\
\text { tailed) }\end{array}$ & .000 & .000 & .000 & .000 \\
\hline & \multirow{2}{*}{$X_{14}$} & $\begin{array}{l}\text { Pearson } \\
\text { Correlation }\end{array}$ & $.481 * *$ & $.614^{* *}$ & $.641 * *$ & $.333^{* *}$ \\
\hline & & $\begin{array}{l}\text { Sig. (2- } \\
\text { tailed) }\end{array}$ & .000 & .000 & .000 & .000 \\
\hline & \multirow{2}{*}{$X_{15}$} & $\begin{array}{l}\text { Pearson } \\
\text { Correlation }\end{array}$ & & $.518^{* *}$ & $.374^{* *}$ & \\
\hline & & $\begin{array}{l}\text { Sig. (2- } \\
\text { tailed) }\end{array}$ & .000 & .000 & .000 & .000 \\
\hline & \multirow{2}{*}{$X_{16}$} & $\begin{array}{l}\text { Pearson } \\
\text { Correlation }\end{array}$ & $.482^{* *}$ & $.476^{* *}$ & $.488 * *$ & $.385^{* *}$ \\
\hline & & $\begin{array}{l}\text { Sig. (2- } \\
\text { tailed) }\end{array}$ & .000 & .000 & .000 & .000 \\
\hline
\end{tabular}

\begin{tabular}{lll}
\hline Keterangan: & \\
$\mathrm{X}=$ Harga & $\mathrm{Y}$ & $=$ Kepuasan Pasien \\
$\mathrm{X}_{11}=$ Daftar Harga & $\mathrm{Y}_{1}=$ Setia \\
$\mathrm{X}_{12}=$ Diskon & $\mathrm{Y}_{2}=$ Pembelian Kembali \\
$\mathrm{X}_{13}=$ Potongan Harga & $\mathrm{Y}_{3}=$ Konsistensi \\
$\mathrm{X}_{14}=$ Periode Pembayaran & $\mathrm{Y}_{4}=$ Rekomendasi \\
$\mathrm{X}_{15}=$ Daya Saing Harga & \\
$\mathrm{X}_{16}=$ Keterjangkauan Harga & \\
\hline
\end{tabular}

Menurut Sugiono (2008) korelasi antar dimensi dapat diinterpretasikan, sebagai berikut:
Tabel 6. Tingkat Kekuatan

\begin{tabular}{c|c}
\hline Koefisien Korelasi & Tingkat Kekuatan Hubugan \\
\hline $0.000-0.199$ & Sangat Lemah \\
\hline $0.200-0.399$ & Lemah \\
\hline $0.400-0.599$ & Sedang \\
\hline $0.600-0.799$ & Kuat \\
\hline $0.800-1.00$ & Sangat Kuat \\
\hline
\end{tabular}

Pada variabel harga dimensi yang paling kuat hubungannya adalah dimensi "periode pembayaran" $\left(X_{14}\right)$ yang memiliki hubungan paling kuat dengan dimensi "konsistensi" $\left(\mathrm{Y}_{3}\right)$ pada variabel kepuasan pasien dengan koefisien korelasi 0,641 (hubungan kuat). Dengan demikian dapat disimpulkan bahwa dimensi harga yang paling menentukan kepuasan pasien pada Rumah Sakit Bhakti Medicare, Cicurug, Kabupaten Sukabumi adalah dimensi harga.

\section{PEMBAHASAN HASIL PENELITIAN}

Hubungan antara harga $(X)$ dengan Kepuasan pasien $(\mathrm{Y})$.

1. Sesuai dengan hipotesis statistik maka hubungan antara harga (X) dengan kepuasan pasien $(\mathrm{Y})$ dengan menggunakan teknik korelasi product moment diperoleh koefisien korelasi $r_{y \cdot 1}=0,679$. Hubungan keduanya signifikan karena $\mathrm{Sig}=0,000$ nilai ini identik dengan $p$-value, yaitu nilai $p$ value lebih kecil dari $\alpha(0,05)$. Dengan demikian $\mathrm{H}_{0}$ ditolak dan $\mathrm{H}_{1}$ diterima, berarti terdapat hubungan positif dan signifikan antara harga $(X)$ dengan kepuasan konsumen $(Y)$.

2. Kontribusi harga $(X)$ dengan kepuasan pasien $(\mathrm{Y})$ dihitung berdasarkan koefisien determinasi yaitu $r^{2}=\left(r_{y .1}\right)^{2}=0,462$. Berarti variabel harga membentuk kontribusi sebesar $46,2 \%$ terhadap kepuasan pasien (Y).

3. Analisis hubungan fungsional antara harga dengan kepuasan konsumen di Rumah Sakit Bhakti Medicare, Cicurug, Kabupaten Sukabumi, diperoleh hasil persamaan hubungan fungsional

$$
\hat{Y}=58,581+0,565 X_{1} \text {. }
$$


Artinya bahwa nilai konstanta (a) sebesar 58,581 berarti bahwa jika nilai harga $(X)$ konstan atau 0 , maka kepuasan pasien sebesar 58,581 dan nilai b sebesar 0,565 artinya setiap peningkatan satu satuan dari harga $(X)$ berarti akan mempengaruhi peningkatan kepuasan pasien sebesar 0,565 satuan.

4. Dimensi yang paling kuat hubungannya adalah dimensi "periode pembayaran" $\left(X_{14}\right)$ yang memiliki hubungan paling kuat dengan dimensi "konsistensi" $\left(\mathbf{Y}_{\mathbf{3}}\right)$ pada variabel kepuasan pasien dengan koefisien korelasi 0,641 (hubungan kuat). Dengan demikian dapat disimpulkan bahwa dimensi harga merupakan variabel yang paling menentukan kepuasan pasien pada Rumah Sakit Bhakti Medicare, Cicurug, Kabupaten Sukabumi.

\section{PENUTUP}

\section{Kesimpulan}

1. Terdapat pengaruh positif antara harga dengan kapuasan pasien dengan nilai koefisien korelasi sebesar 0,679 masuk dalam kategori hubungan kuat. Sedangkan kontribusi harga terhadap kepuasan pasien sebesar 46,2\% sehingga kepuasan pelanggan dapat ditingkatkan melalui strategi penetapan harga secara cermat.

2. Variabel harga membentuk kontribusi sebesar $46,2 \%$ terhadap kepuasan pasien (Y).

3. Dimensi "periode pembayaran" $\left(X_{14}\right)$ yang memiliki hubungan paling kuat dengan dimensi "konsistensi" $\left(Y_{3}\right)$ pada variabel kepuasan pasien dengan koefisien korelasi 0,641 (hubungan kuat). Dengan demikian dapat disimpulkan bahwa dimensi harga yang paling menentukan kepuasan pasien.

4. Hubungan Fungsional antara harga dengan kepuasan pasien dapat dilihat pada persamaan:

$$
\hat{\mathrm{Y}}=58,581+0,565 X
$$

Persamaan di atas menunjukkan bahwa harga berpengaruh positif terhadap kepuasan pelanggan dengan koefisien regresi sebesar 0,565 yang artinya kepuasan pasien akan meningkat 0,565 satuan apabila variabel harga $(X)$ meningkat satu satuan dengan konstansta 58,581.

\section{Implikasi}

Kepuasan pelanggan adalah suatu perasaan senang yang langsung dirasakan oleh pelanggan ketika harapan pelanggan terhadap suatu produk terpenuhi atau bahkan melampaui harapan pelanggan. Ketika seorang pelanggan merasa puas maka pelanggan bisa melakukan pembelian ulang kembali bahkan pelanggan akan berbagi pengalaman yang menyenangkan kepada kerabat mereka atas hasil yang memuaskan dirinya setelah mengonsumsi produk tersebut.

Kepuasan pelanggan berdampak penting bagi kelangsungan usaha Rumah Sakit Bhakti Medicare, Cicurug, Kabupaten Sukabumi karena dapat menciptakan loyalitas pelanggan berupa word of mouth yang positif dan pembelian ulang sehingga jumlah pelanggan akan bertahan atau meningkat yang pada akhirnya akan mempertahankan dan meningkatkan pendapatan dan keuntungan Rumah Sakit Bhakti Medicare, Cicurug, Kabupaten Sukabumi.

Kepuasan pelanggan juga dapat meningkatkan daya saing Rumah Sakit Bhakti Medicare, Cicurug, Kabupaten Sukabumi serta siap berkompetisi. Selain pesaing dari kawasan Kabupaten Sukabumi, terdapat juga pesaing dari luar kawasan Kabupaten Sukabumi seperti kawasan Kota Sukabumi dan Bogor yang juga meningkat pertumbuhan pembangunan rumah sakitnya.

Berdasarkan kesimpulan penelitian ini kepuasan pelanggan dapat ditingkatkan melalui dimensi "periode pembayaran" yang mencakup uang muka, pelunasan, pemberian tempo pembayaran dan periode pembayaran dan kualitas pelayanan baik yang mencakup 
dimensi "reliability" (kehandalan) secara parsial atau secara bersama-sama. Oleh karena itu rumusan implikasi penelitian ini menekankan pada upaya-upaya dalam meningkatkan skema pembayaran sehingga kepuasan pelanggan dapat meningkat.

Harga adalah pandangan pelanggan dalam melihat harga dilihat dari tinggi dan rendahnya harga yang mempengaruhi keputusan pembelian. Pandangan harga yang mengacu pada indikator harga yaitu : 1) Daftar harga; 2) Diskon; 3) Potongan harga; 4) Periode pembayaran; 5) Daya saing harga dan 6) Keterjangkauan harga, dapat mempengaruhi pelanggan dalam memuaskan keinginannya. Pandangan harga melalui indikator harga akan memberikan kenyamanan kepada pelanggan untuk bertransaksi. Semakin baik pandangan harga pelanggan maka akan membuat pelanggan semakin nyaman dan senang dalam mengkonsumsi layanan yang diberikan kepadanya. Bila pandangan harga pelanggan memenuhi standar sesuai harapan pelanggan, maka pelanggan akan puas. Demikian juga sebaliknya, bila tidak sesuai dengan harapannya maka pelanggan akan kecewa atau tidak puas. Dengan demikian dapat diduga bahwa terdapat hubungan antara harga dengan kepuasan pelanggan.

Adapun upaya peningkatan kepuasan pelanggan melalui harga dapat dilakukan dengan cara menginformasikan daftar harga secara jelas, memberikan diskon kepada pelanggan sesuai profilenya (tingkat ekonomi atau keluarga karyawan), memberikan potongan harga secara tepat, melakukan bench marking terhadap harga-harga rumah sakit sekitar untuk melihat daya saing dan keterjangkauan harga terutama dan yang paling kuat pengaruhnya adalah pemberian skema periode pembayaran yang lebih bervariatif misalnya dengan bekerja sama dengan lembaga pembiayaan dan asuransi.

\section{Saran}

Hal-hal yang perlu ditingkatkan dalam penetapan harga:
1. Menerapkan strategi periode pembayaran yang lebih baik untuk mempengaruhi persaingan.

2. Melakukan benchmarking kepada rumah sakit-rumah sakit untuk terus mengevaluasi kebutuhan menyesuaikan harga karena adanya kekuatan eksternal yang mempengaruhi dan adanya perubahan dalam daur hidup produk/jasa.

3. Meningkatkan ruang perawatan, tempat tidur, kasur dan desain interior yang menarik.

4. Menetapkan tarif biaya administrasi yang optimum dan penghapusan biaya-biaya pasien yang tidak perlu.

5. Meningkatkan kualitas atribut-atribut produk sehingga dapat digunakan dalam waktu yang lama.

6. Rumah Sakit Bhakti Medicare, Cicurug, Kabupaten Sukabumi perlu menyesuaikan diri dan mengikuti trend dalam persaingan produk rumah sakit.

\section{REFERENSI}

Artiningtyas, I. (2015). Pengaruh Kualitas Layanan, Persepsi Harga Dan Kepercayaan Terhadap Kepuasan Pelanggan (Studi Kasus Pada Toko Vulkanisir Ban Top Cool Semarang). Jurnal of Management, Volume 1 Nomor 1 Februari 2015, ISSN : 2502-7689. Semarang: Fakultas Ekonomi Universitas Pandanaran.

Baines, P., C. Fill, and K. Page. (2011). Marketing. New York: Oxford University Press, 2011, hal. 331-332.

Harjati, L. dan Venesia, Y. (2015). Pengaruh Kualitas Layanan dan Persepsi Harga Terhadap Kepuasan Pelanggan pada Maskapai Penerbangan Tiger Air Mandala. E-Journal WIDYA Ekonomika, Volume 1 Nomor 1 Oktober 2015, ISSN 2338-7807. Jakarta: Widya Ekonomika.

Iman, Riga N. (2013). Pasca-Lebaran, Pasien yang Berobat di Rumah Sakit Meroket". Republika Selasa, 13 Agustus 2013. 
JIMFE (Jurnal Ilmiah Manajemen Fakultas Ekonomi)

https://journal.unpak.ac.id/index.php/jimfe

Irawan, H. (2002). 10 Prinsip Kepuasan Pelanggan. Jakarta: PT. Elex Media Komputindo.

Sugiono. (2008). Metode Penelitian Pendidikan Kuantitatif, Kualitatif dan R\&D. Bandung: Penerbit CV Alfabet.

Tjiptono, F. (2007). Strategi Pemasaran. Edisi Kedua. Yogyakarta: Penerbit Andi.

Umar, A, et al. (2015). Customer satisfaction as mediator between price, trust and brand loyalty: A case study from Malaysia.
Vol. 4 No. 1, Juni 2018, Hal. 41-50

P-ISSN: 2502-1400, E-ISSN: 2502-5678

Malaysia: Universiti Teknologi Malaysia.

Tersedia

di:

https://www.researchgate.net/publicati on/327574473_Customer_satisfaction_ as_mediator_between_price_trust_and _brand_loyaltyCase_study_from_Malay sia

Zeithaml, V, A \& Bitner, M, J \& Gremler, D, D. (2009). Service Marketing, Edisi Lima. United States of America: Mc Graw Hill. 
